\title{
Evaluating the English Textbook "IRAQ OPPORTUNITIES" Book 6 for the 2nd Intermediate Stage
}

\author{
Dr. Hanan D. Akef \\ University of Baghdad/College of Education for Girls / English \\ Department
}

\begin{abstract}
:
The researcher as a teacher of English intended to evaluate the $2^{\text {nd }}$ Intermediate stage English textbook "Iraq Opportunities" since it was adopted by the Ministry of Education in the year 2010/2011. After reviewing the desired book, the researcher found out that this textbook have many weak issues need to be studied, analyzed and evaluated. Since then, the researcher has been in contact with the teachers who teach this textbook. Some often complain of the difficulties in dealing with the textbook; others are dissatisfied with the results of the students' achievement tests and not satisfied with the students' comprehension to the material existed in this book which covered by poor production.
\end{abstract}

This study aims at:

1- Evaluating the English Textbook "IRAQ OPPORTUNITIES" for the $2^{\text {nd }}$ Intermediate stage by teachers' perspective.

2- Review teachers' suggestions and recommendations which help in developing the Textbook.

This study is limited to:

1- The English Textbook "IRAQ OPPORTUNITIES" for the $2^{\text {nd }}$ Intermediate stage.

2- $\quad$ An EFL teachers of $2^{\text {nd }}$ intermediate stage at secondary and intermediate schools existed at Baghdad/Al-Karkh (1).

\section{Introduction}

\section{1- Statement of the problem}

The researcher as a teacher of English intended to evaluate the $2^{\text {nd }}$ Intermediate stage English textbook "Iraq Opportunities" since it was adopted by the Ministry of Education in the year 2010/2011. After reviewing the desired book, the researcher found out that this textbook have many weak issues need to be studied, analyzed and evaluated. Since then, she has been in contact with the teachers who teach this textbook. Some often complain of the difficulties in dealing with the textbook; others are dissatisfied with the results of the students' achievement tests and not satisfied with the students' comprehension to the material existed in this book which covered by poor production. The educational system in Iraq 
adopted several of the English language teaching textbooks, but none of these textbooks succeeded in achieving the desired English proficiency level. The main reason for this failure could be related to the designing factor of these textbooks. All the English textbooks that were and are still in use at the school level in Iraq are not based on a scientific and systematic investigation of the real situation in Iraq. They were designed either to be used in other countries for different learners or for commercial purposes. Even those textbooks, which were designed especially for Iraq, were designed not by specialized persons. The authors did not investigate the real English language-teaching situation before starting the development process.

The researcher aims at evaluating this textbook so that it can help teachers to meet the text designers' desires and interests; It can also help them deal with the different subjects in the textbook, and foster what is good about the book and the areas to be modified.

It is true that many studies have dealt with evaluating English textbooks, but these are still inadequate, and to the best of the researcher's knowledge, this is the first one to evaluate the new English textbook $-2^{\text {nd }}$ Intermediate stage in Iraq.

\section{2- Significance of the Study}

There are different views concerning why we evaluate materials used for teaching English. Hutchinson and Waters (1987) see it as an analytical "matching process: matching needs to available solutions". This, they suggested, can be done according to the sponsor's needs through a needs analysis. While this perspective is important, it is incomplete since it leaves out the views of other interested parties, such as the teachers and the learners (ibid, p. 97)

Materials evaluation is an educational necessity because it shows how a textbook can be improved or justified. Teaching materials have a direct influence on the process of learning and teaching. Nunan (1988) states that: materials are, in fact, an essential element within the curriculum, and do more than simply lubricate the wheels of learning. At their best, they provide concrete models for desirable classroom practice. They act as curriculum models and at their very best they fulfill a teacher development role (Nunan, 1988, p. 98).

Dougill (1987) also proposes a framework consisting of a list of chief considerations that he thinks are necessary for a reviewer to keep in mind. No doubt, whatever form they take, be it in checklist, framework or 
evaluation sheet, they all ask the right and essential questions concerning the issue of assessing a textbook. These questions serve as guidance for material evaluators when they scrutinize a particular textbook they are using or they are going to select or adapt.

The textbook proposed for evaluation is the textbook adopted for use in Iraqi $2^{\text {nd }}$ Intermediate schools. Since this is the introduction to English for Iraqi students, it is important for the textbook to be engaging enough to excite the students' interest, but still to thoroughly present the fundamentals of English in an age appropriate manner. This makes the evaluation of the textbook a matter of high importance. Palmer (1922) stated that "If we take care of the intermediate stage, the advanced stages will take care of themselves" (p. 13).

Since English is considered as today's language of international commerce and transaction, the oil-rich Iraq country cannot afford to be left out while its neighbors and countries around the world are improving their English literacy. This timely evaluation, along with others, may prove to be a valuable input to the Ministry of Education by serving as a possible guide for similar future textbook evaluations.

\section{3- Aims of the Study}

This study aims at:

3- $\quad$ Evaluating the English Textbook "IRAQ OPPORTUNITIES" for the $2^{\text {nd }}$ Intermediate stage by teachers' perspective.

4- Review teachers' suggestions and recommendations which help in developing the Textbook.

\section{4- Limits of the Study}

This study is limited to:

3- The English Textbook "IRAQ OPPORTUNITIES" for the $2^{\text {nd }}$ Intermediate stage.

4- An EFL teachers of $2^{\text {nd }}$ intermediate stage at secondary and intermediate schools existed at Baghdad/Al-Karkh (1).

\section{5- Definition of BasicTerms}

1. Evaluation: Brown \& Rogers (2002) define the term evaluation as "the process of seeking to establish the value of something for some purpose" (Brown \& Rogers, 2002, p. 289). 
2. Foreign language: "A language which is not normally used for communication in a particular society" (Tomlinson, 1998, p. x).

3. English Textbook: A textbook is a book used for instructional purposes, especially in schools and colleges. (Matos. F, 2000)

4. $\quad \mathbf{2}^{\text {nd }}$ Intermediate stage: it refers to the stage in which students who study EFL in Iraq by the newly prescribed text book entitled "Iraq Opportunities".

\section{Literature Review}

\section{1- Theoretical Background}

\section{- What is Evaluation?}

Banks (1977), pp.489-490) considers evaluation as a technical aspect of instruction and a part of the teaching/learning process that gives continuous feedback of data to keep the system in adjustment. Nevo (1977, p.127) states," Evaluation refers to the process of delineating, obtaining and providing information on the merit of goals, designs, implementation and outcomes of educational activities, and should help to improve educational activities, and should help to improve an educational product during the process of its development, and/or demonstrate the merit of the final product when its development is completed."

\section{- Purposes of Evaluation}

Evaluation has many purposes but the main purposes of evaluation include examining the effectiveness of the instructional material, giving important information about the students' progress and curriculum development."Analysis and evaluation provide useful data to teachers, supervisors and other educational departments with concrete evidence regarding strong and weak points of evaluative books. Likewise, they include important information that addresses the needs of teachers and students which can be divided into teacher- centred and student- centred". (Azevendo: 1979)

The main goal of evaluation studies is not merely to evaluate, but rather to obtain useful information for improving the curriculum and the textbooks and that can help in testing and measuring the student's achievements.

Sawin, (1990) maintains that "Evaluation studies can shed light on the points of strengths and weaknesses of the syllabus in order to enhance what is good and deal with the areas that may need to be improved.

"There are two major purposes for language program evaluation: programme accountability and programme development. These are 
interrelated with formative evaluation and summative evaluation.' (Ibid, 2001:288)

\section{Accountability:}

This refers to the extent to which those involved in a programme are answerable for the quality of their work. It is concerned with the examination of the effects of a programme or project at a significant point of an educational cycle. It is usually conducted for the benefit of an external audience or a decision maker. (Richard, 2001:298)

\section{Programme Development:}

This is designed to improve the quality of a programme as it is being implemented. Involved or non-involved staff in the programme may be engaged in the evaluation process. A teacher-development focus may be involved as well. (Richards, 2001:288)

Analysis and evaluation have played roles in evaluating curriculum, decision making and policy information, assessing students' achievement and in improving educational materials and programmes.

\section{- $\quad$ Types of Evaluation}

\section{a. Formative Evaluation:}

The purposes of formative evaluation are to evaluate what is effective and to change what isn't so that the course effectively meets the students' needs, to give students a voice in their learning, to provide information for the design of the course. (Graves, 2000: 215)

\section{b. Summative Evaluation}

Summative evaluation seeks to make decisions about the worth or value of different aspects of the curriculum. It is concerned with determining its effectiveness, efficiency and acceptability. (Richards, 2001: 292)

\section{c. Illuminative Evaluation}

The purpose of this type of evaluation is not to change the course necessarily but to find out the work of different aspects of the programme and how they are implemented. It is concerned with establishing a deeper understanding of the processes of teaching and learning that occur in the programme. (Richards, 2001: 289)

Evaluation studies played many roles in education including the following:

- $\quad$ providing a basis for decision making and policy information.

- $\quad$ assessing student achievement.

- $\quad$ accrediting schools 
- $\quad$ monitoring expenditure of public funds.

- improving educational materials and programmes (Worthen and Sanders: 1987)

\section{- $\quad$ Textbook Evaluation}

A textbook is a book used for instructional purposes, especially in schools and colleges. (Matos F, 2000).

The adopted textbook stands in the middle, as a link or a tool between the English programme and the teaching situation (Williams: 1983:254, and Mariani: 1980:28).

There are three main reasons for using a textbook:

1- It is difficult for the teachers to develop their classroom materials.

2- $\quad$ The time available for the teacher is limited while developing new material takes a great amount of time.

3- The outside restriction of pressure affects the teacher. (Sheldon, 1988).

Textbooks have many advantages because they provide:

- $\quad$ structure and a syllabus for a programme.

- a variety of learning resources such as, visuals, activities, reading and so on.

- $\quad$ security for the students as they know what to expect and what is expected from them.

- $\quad$ a basis for assessing students' learning.

- $\quad$ consistency with a programme across a given level.

- $\quad$ training teachers as they provide a teacher's manual.

\section{2- $\quad$ Previous Studies}

Since evaluation is considered as an integral part in the educational process, many researchers have been very enthusiastic to conduct their studies in this field for the sake of the textbook improvement and modification as follows:

1- Mahmoud, (2008) : 
It aimed to evaluate the effectiveness and suitability of "English for Palestine-10 textbooks". The researcher used two instruments: a 52- item questionnaire, and the characteristics of a good textbook. The sample of the study consisted of 50 male and female English teachers who teach the tenth graders from Nablus district.

Mahmoud, (2006) had also evaluated ' English for Palestine 1V '. He used a similar instrument in order to judge the suitability of a good TEFL or ESL text book. The sample of the study consisted of 60 teachers who teach the fourth grade from Jenin and Qabatia districts. In both studies he found out that the textbooks he analyzed were suitable but lacked few items that characterize a good textbook. He noticed that:

- $\quad$ Teachers, supervisors and parents as well as the local society did not participate in selecting the materials or in choosing the objectives of the curriculum.

- Designers should consider the country's environment in the materials included in the books activities.

- The textbooks should be revised carefully to make sure they are free of mistakes.

- The number of the periods per week is not sufficient to cover the selected material of the fifth grade.

- There should be a balance between the aims, the materials and the number of periods designed to render the whole message to the students.

- $\quad$ The students' book should have a glossary, proper pronunciation and phonetic transcription of each word and an index listing the key words with their meanings and page number.

\section{2- Badawi, (2007):}

It aimed to evaluate the content of English for Palestine Grade 10 textbook, which was designed on for the tenth basic grade students in the West Bank and Gaza Strip and has been taught since 2004-2005. He used the descriptive analytical method of research to carry out the study. He designed an analysis card that sought to collect data relevant to process the study. These data involved making a survey for the textbook so as to analyze the activities that match the standards set by the study. The analysis card was shown to 12 experts for benefiting from their comments in regard to any potential modifications, deletions and additions to achieve validity. Reliability was examined through the help of three researchers. The 
findings of the study showed a variance in presenting the standards of the foreign language learning. Communications standards were highly dominant in contrast with communities, connections and cultures standards. He pointed out that there should be more balance in the distribution of the standards among the units of the textbook. The findings also showed good employment for topics in the textbook. Various topics were introduced throughout the twelve units. The study recommended establishing a follow up research committee in order to apply formative and summative evaluation researches to achieve more innovations and developments. Teachers were invited to attend workshops held by the Ministry of Education on new trends in area of curriculum and teaching, and employ more effective methods such as group work, team work and cooperative learning methods.

The two previous studies (Mahmoud's and Badawi's) agreed that there is a variety in the topics of the textbook units. On the other hand, there should be more balance in the distribution of the standards among the units, and the textbooks ought to be evaluated and revised continually.

3- Masri, (2003):

It evaluated the first grader's new English textbook English for Palestine from teachers' perspective in the Northern District of Palestine. The study sought to determine the role of the gender, educational level, and years of experience variables on the degree of evaluation. A questionnaire was developed for the purpose of this study. The size of the proposed population was 350 teachers. The sample was chosen randomly and it consisted of 208 teachers.

The results showed that the degrees of evaluation of the book shape domain, the book content domain, the structure of the language and the grammar, and the methods and aids were high with total score. Significant differences were found in the degree of evaluation between male and female teachers in favour of males, and there were significant differences due to experience.

Masri recommended that teachers should:

- keep up with modern trends in teaching English as a foreign language; they ought to create new methods and techniques in teaching English for Palestine Grade 1.

- $\quad$ concentrate on using tapes and cards.

- $\quad$ vary their techniques so as to deal with the individual differences among their students. 
- $\quad$ organize school workshops so that they can exchange experience and discuss recent educational trends, such as developing students' cognitive skills, promotion of self-learning, and life-long educational skills.

She also recommended that workshops, programmes and seminars are to be held for EFL teachers in order to keep teachers focus on the effective techniques that help increase students' interaction and involvement in the classroom.

Mahmoud and Masri's studies both emphasised that EFL teachers ought to keep in contact with the modern effective trends of teaching through attending the seminars and taking part in the workshops held from time to time by the Ministry of Education so that they can achieve students' progress and better interaction in the classroom.

\section{PROCEDURES}

\section{1- Population of the Study}

The population of this study included English teachers of intermediate stage at Baghdad/ AL-Karkh (1) during the academic year (2010-2011) and intermediate and secondary schools at Baghdad/ AL-Karkh (1) during the academic year (2010-2011).

A- Population of intermediate and secondary schools

It consisted of (83) schools in Baghdad / AL-Karkh (1) according to the statistics provided by the ministry of Education for the academic year (2010-2011) Appendix (1).

B- Population of the English teachers

It consisted of (100) public and private intermediate school English teachers according to the statistics provided by the ministry of Education for the academic year (2010-2011).

\section{2- $\quad$ Pilot Administration}

A group of 20 teachers have been selected for the sake of conducting a pilot administration of the instrument: the checklist. The pilot sample represents 20 teachers selected from the whole population out of the basic sample of the current study.

\section{3- Sample of the Study}


A. Sample of intermediate and secondary schools:

It consisted of (60) intermediate schools in Baghdad /AL-Karkh (1) randomly selected from the whole population of the intermediate schools Appendix (2).

B. Sample of the English teachers

The sample of this study consisted of (60) male and female English teachers drawn from 60 secondary schools randomly selected from the whole population of the intermediate schools. The researcher chose one teacher from each school.

\section{4- Data Collection}

The researcher distributed the copies of the checklist to male and female teachers. The number of males (26) is fewer than females (34) because some female teachers teach in boys' schools. In order to obtain more valid and credible results, teachers were given the freedom to complete the checklist either immediately. The researcher managed to collect almost all the copies.

Then the questionnaire was statistically analysed. These teachers participated in ensuring the reliability of the checklist. Alpha formula was also used to determine this reliability.

\section{5- Instrumentation}

In order to achieve the aims set in the present study, and to get valid results, the researcher has utilized the following instrument: a checklist for teachers. It is the suitable instrument to achieve the aims in a short time.

\section{i- $\quad$ The Checklist}

A checklist, as an instrument of research, is one of an inquiring form that "include data gathering instruments through which respondents answer questions or respond to statements in writing (Best 1981: 167).

In order to build the instrument (checklist), the researcher did the following:

1- Send an open questions questionnaire to the selected teachers of the pilot sample who were (20). The open questions questionnaire consisted of three questions:

- The first was: what are the positive issues you found at the English Textbook IRAQ OPPORTUNITIES for the $2^{\text {nd }}$ Intermediate Stage? 
The second was: what are the negative issues you found at the English Textbook IRAQ OPPORTUNITIES for the $2^{\text {nd }}$ Intermediate Stage?

- $\quad$ The third one was: what are your suggestions for developing English Textbook IRAQ OPPORTUINITIES for the $2^{\text {nd }}$ Intermediate Stage? Appendix (3).

2- After having much information from the open questions questionnaire about the textbook, the researcher found that is not enough and it must have additional information help in building the checklist items.

Therefore the researcher dealt with other resources such as:

1- Reviewing the previous studies related to the subject of the current study such as: Hatamleh and Jaradat, (1984), Chaplen, (1980), and AlJarrah, (1987).

2- Reviewing the literatures and references that dealt with criteria of evaluating schools English textbooks such as: Byrd, 2001, Skierso, 1991, and Daoud \& Celce-Murcia, 1979.

3- The researcher depends on her experience in teaching and her information and knowledge about evaluating textbooks.

In the light of that, the researcher wrote the checklist with its initial form and reviewed on a number of experts to ensure its validity. After that, the checklist has been modified according to the experts' notes and modifications and reaches its final form. The type of checklist used in the present study is a restricted or closed form which calls for ticking.

The researcher developed a 42- item checklist in addition to one open question at the end of the checklist: Appendices (4) and (5) to evaluate the English textbook "Iraq Opportunities" for the $2^{\text {nd }}$ Intermediate stage. The checklist is based on Byrd, 2001, Skierso, 1991, Daoud \& Celce-Murcia, 1979, Sheldon, 1988, Hu \& Nation, 2000, Wixton, 1989, Moran, 1991, Auerbach \& Paxton, 1997, Lee, 2003, Lynch, 2001, Salataci \& Akyel, 2002, Watanabe, 1997, Blohm, 1981, Newman, 1996, Krashen, 1997, Sharifan, 1999, Eskey \& Grabe,1988, Kramsch, 1993, Fishman, 2003, Graves, 1996, Goodman, Shannon, Freeman, \& Murphy, 1988, Monahan \& Hinson, 1988.

The items of the checklist were grouped under two main fields in addition to one open question at the end of the checklist:

I. The textbook 


\section{Teacher's Manual}

The textbook field consisted on four domains:
A. General Shape: which included (6) items $(1,2,3,4,5,6)$
B. Objectives: which included (6) items $(7,8,9,10,11,12)$
C. Content: which included three domains:
1- Reading and writing: which included (6) items (13, 14, 15, 16, 17, 18)

2- $\quad$ Structure and vocabulary: which included (6) items (19, 20, 21, $22,23,24)$

3- Listening and speaking: which included (5) items (25, 26, 27, 28, 29)

D. Teaching Aids: which included (6) items (30, 31, 32, 33, 34, 35)

The teacher's manual field consisted on three domains:
A. General Features: which included (2) items $(36,37)$
B. Background Information: which included $(2)$ items $(38,39)$
C. Methodological Guidance: which included (3) items $(40,41,42)$

III. What are your suggestions and recommendations for developing English Textbook IRAQ OPPORTUINITIES for the $2^{\text {nd }}$ Intermediate Stage?

\section{6- Validity of the Instrument}

Validity is the first aspect to be checked when constructing any type of instrument. Harris (1969: 19) puts his view of validity within two questions: "(1) What precisely does the test measure?" and "(2) How well does the test (instrument) measure?". Brown, (1987: 221) states that validity refers to "the degree to which a test actually measures what is intended to measure".

Richards et al. (1992: 396) define validity as "the degree to which a test (instrument) measures what it is supposed to measure, or can be used 
successfully for the purpose for which it is intended". Gipps (1994: 58) defines validity as the extent to which an assessment measures what it is supposed to measure.

There are several types of validity such as face validity, content validity, construct validity, etc. Content validity is the suitable type to find out whether the instrument is valid to achieve the aims of the present study or not. To achieve the content validity of the instrument, the checklist was given to a jury of qualified instructors in the field of teaching English as a foreign language at Baghdad University/College of Education (Ibn Rushd), Al-Tikrit University/ College of Education, and Al-Mustanssiria University / College of Arts (table 1) who approved it with minor modifications which were taken care of.

Table 1

Names of Jury Members

\begin{tabular}{|c|c|l|c|c|}
\hline No. & $\begin{array}{c}\text { Academic } \\
\text { Rank }\end{array}$ & \multicolumn{1}{|c|}{ Name } & Field & College \\
\hline 1 & Professor & Al-Nassiri, Nahida T. PhD & ELT & College of Education/ University of Tikrit \\
\hline 2 & $\begin{array}{c}\text { Assistant } \\
\text { Professor }\end{array}$ & Sa'eed, Mu'ayad M. PhD & ELT & $\begin{array}{c}\text { College of Education/Ibn Rushd, } \\
\text { University of Baghdad }\end{array}$ \\
\hline 3 & Professor & Al-Rifa'i, Fatin K. PhD & ELT & $\begin{array}{c}\text { College of Education/Ibn Rushd, } \\
\text { University of Baghdad }\end{array}$ \\
\hline 4 & Instructor & $\begin{array}{l}\text { Al-Timimi, Salam Hamid. } \\
\text { Ph.D }\end{array}$ & ELT & $\begin{array}{c}\text { College of Education/Ibn Rushd, } \\
\text { University of Baghdad }\end{array}$ \\
\hline 6 & Pssistant & $\begin{array}{l}\text { Al-Marsoomi, Istiqlal. } \\
\text { Ph.D }\end{array}$ & ELT & $\begin{array}{c}\text { College of Arts, University of } \\
\text { Mustansiriyah }\end{array}$ \\
\hline
\end{tabular}

\section{7- Reliability of the Instrument}

Reliability is one of the necessary characteristics of any good instrument. It should refer to the consistency of measurement which makes validity possible and indicates the amount of confidence that can be placed in the results of a test (Oller, 1979: 4).

In practice, it is well known that even the same test when reconducted at a later time to the same group of testees, under the same conditions; it is 
unlikely to yield exactly the same scores. However, the more comparable the test scores are, the more reliable they are (Wells \& Wollack, 2003: 13). Accordingly, the reliability coefficient of the questionnaire has been computed by using Alpha-Cronbach Formula (Table 2)

Table (2): Alpha formula of instrument Reliability

\begin{tabular}{|c|c|}
\hline \multicolumn{1}{|c|}{ Domains } & Reliability \\
\hline I. $\quad$ Textbook & 0.78 \\
\hline A. General Shape & 0.71 \\
\hline B. $\quad$ Objectives & 0.78 \\
\hline C. $\quad$ Content & 0.79 \\
\hline D. $\quad$ Teaching Aids & \\
\hline II. $\quad$ Teacher's Guide & 0.77 \\
\hline A. $\quad$ General Features & 0.78 \\
\hline B. $\quad$ Background Information & 0.78 \\
\hline C. $\quad$ Methodological Guidance & 0.87 \\
\hline
\end{tabular}

The results of table (4) show that the range of reliability of domains was between $(0.71-0.79)$, and total score $(0.87)$ which means that all of these values are suitable for conducting such a study according to Mehrens and Lehmann (1991: 255).

\section{8- The Scoring Scheme}

Regarding the questionnaire, the scale is of five ratings, the scoring scheme adopted in the present study is to give a mark for each rating scale as shown below:

Excellent 5, Good 4, Adequate 3, weak 2, and totally lacking 1

\section{9- Procedure}

The researcher developed a 42-item checklist and achieved the reliability and validity of the instrument. The sample of the study consisted of 60 English teachers. The copies of the checklist form were distributed and 
collected by the researcher herself. In order to analyse the data, the researcher used pertinent statistical techniques such as (SPSS) statistical packages, descriptive statistics, means, standard deviations and percentages to achieve the aims of the study, and Independent t-test, One -Way ANOVA, and MANOVA. Finally, the results of the study were discussed and recommendations were put forth.

\section{Discussion of Results}

\section{1- Results}

\section{- Results Related to the First Aim}

The first aim of this study is: evaluating the English Textbook "IRAQ OPPORTUNITIES" for the $2^{\text {nd }}$ Intermediate stage. In an attempt to achieve the aim, means and percentages of each checklists' item and the total score of each English skill were calculated.

For data analysis, a five- point scale was used, and the percentages were as follows:

1. $(80 \%)$ and more is a very high degree of evaluation.

2. (70-79.9\%) is a high degree of evaluation.

3. $(60-69.9 \%)$ is a moderate degree of evaluation.

4. $(50-59.9 \%)$ is a low degree of evaluation.

5. (Less than $50 \%$ ) is a very low degree of evaluation.

\section{Textbook}

\section{A. General Shape Domain:}

Table (3) Means and percentages of the Evaluation

\begin{tabular}{|c|c|c|c|c|}
\hline No & Items & $*$ Means & $\begin{array}{c}\text { Percent } \\
(\%)\end{array}$ & Degree \\
\hline 1 & The outside cover of the book is attractive & 3.65 & 73 & High \\
\hline 2 & The textbook paper is of good quality & 3.81 & 76.2 & High \\
\hline 3 & The textbook is rich with illustrations that facilitate & 3.56 & 71.2 & High \\
\hline 4 & students' learning & & & Low \\
\hline 5 & The textbook is free of mistakes & 2.95 & 59 & Very High \\
\hline 6 & The textbook has a list of contents & 4.01 & 80.2 & Moderate \\
\hline \multicolumn{2}{|r|}{ Total score of Textbook General Shape domain } & $\mathbf{3 . 5 9}$ & $\mathbf{7 1 . 8}$ & High \\
\hline
\end{tabular}


The results of table (3) show that the degree of evaluation for textbook general shape domain was very high on item (5), where the percentage of response on this item was (80.2\%). The degree was high on items $(1,2$, and 3 ) where the percentages of response on these items were between

$(71.2 \%-76.2 \%)$. The degree was moderate on item (6) where the percentage of response on this item was $(69.6 \%)$. The degree was low on item (4) where the percentages of response on this item were $(59 \%)$.

For the total score of the textbook general shape, the degree was high where the percentage of response was $(71.8 \%)$.

B. Objectives Domain:

Table (4) Means and percentages of the Evaluation

\begin{tabular}{|c|c|c|c|c|}
\hline No & Items & *Means & Percent $(\%)$ & Degree \\
\hline 7 & are related to the learners' needs and interests & 3.30 & 66 & Moderate \\
\hline 8 & are clear and specific & 3.53 & 70.6 & High \\
\hline 9 & $\begin{array}{l}\text { correspond with the modern developments around } \\
\text { the world }\end{array}$ & 3.83 & 76.6 & High \\
\hline 10 & are relevant to the local culture & 3.15 & 63 & Moderate \\
\hline 11 & meet the individual differences among students & 2.78 & 55.6 & Low \\
\hline 12 & $\begin{array}{l}\text { make a balance between the four main skills, } \\
\text { listening, speaking, reading and writing }\end{array}$ & 3.73 & 74.6 & High \\
\hline \multicolumn{2}{|r|}{ Total score of Textbook Objectives domain } & 3.62 & 72.4 & High \\
\hline
\end{tabular}

The results of table (4) show that the degree of evaluation for textbook objectives domain was high on items $(8,9$, and 12$)$ where the percentages of response on these items were between (70.6\%-76.6\%). The degree was moderate on items (7 and 10) where the percentage of response on these two items were between $(63 \%-66 \%)$. The degree was low on item (11) where the percentages of response on this item were $(55.6 \%)$.

For the total score of the textbook objectives domain, the degree was high where the percentage of response was $(72.4 \%)$.

\section{Content Domain:}

Table (5) Means and percentages of the Evaluation

\begin{tabular}{|c|c|c|c|c|}
\hline No & Items & *Means & $\begin{array}{c}\text { Percent } \\
(\%)\end{array}$ & Degree \\
\hline \multicolumn{5}{|c|}{ 1. Reading and Writing } \\
\hline 13 & $\begin{array}{l}\text { contains a sufficient number and a variety of reading } \\
\text { passages }\end{array}$ & 3.81 & 76.2 & High \\
\hline 14 & $\begin{array}{l}\text { helps students develop fluency and enjoyment in } \\
\text { reading }\end{array}$ & 3.28 & 65.6 & Moderate \\
\hline 15 & $\begin{array}{l}\text { Many of the reading passages are up-to-date and } \\
\text { meaningful }\end{array}$ & 3.70 & 74 & High \\
\hline 16 & $\begin{array}{l}\text { Some writings are difficult for most of the students to } \\
\text { deal with }\end{array}$ & 3.83 & 76.6 & High \\
\hline
\end{tabular}




\begin{tabular}{|c|c|c|c|c|}
\hline 17 & enhances free writing opportunities & 2.96 & 59.2 & Low \\
\hline 18 & The time allotted for teaching the material is sufficient & 2.35 & 47 & Very low \\
\hline \multicolumn{2}{|c|}{ Total score of Reading and Writing sub-domain } & 3.50 & 70 & High \\
\hline \multicolumn{5}{|c|}{ 2. Structure and Vocabulary } \\
\hline 19 & Structures are designed to be taught inductively & 3.67 & 73.4 & High \\
\hline 20 & The grammar is graded Appropriately & 3.71 & 74.2 & High \\
\hline 21 & $\begin{array}{l}\text { Grammar lessons are often derived from the reading } \\
\text { passages }\end{array}$ & 3.80 & 76 & High \\
\hline 22 & $\begin{array}{l}\text { The topical nature of the vocabulary exercises are } \\
\text { often meaningful to the students }\end{array}$ & 3.51 & 70.2 & High \\
\hline 23 & $\begin{array}{l}\text { Grammar and vocabulary are appropriate to the } \\
\text { students' level }\end{array}$ & 3.31 & 66.2 & Moderate \\
\hline 24 & The time allotted for teaching the material is sufficient & 2.21 & 44.2 & Very low \\
\hline \multicolumn{2}{|r|}{ Total score of Structure and Vocabulary sub- domain } & 3.52 & 70.4 & High \\
\hline \multicolumn{5}{|c|}{ 3. Listening and Speaking } \\
\hline 25 & Cassettes are of high quality production & 3.67 & 73.4 & High \\
\hline 26 & $\begin{array}{l}\text { The cassettes expose the students to the voices and } \\
\text { pronunciation of the native speakers of English }\end{array}$ & 3.00 & 60 & Moderate \\
\hline 27 & $\begin{array}{l}\text { The listening exercises often focus on stress, rhythm, } \\
\text { and intonation }\end{array}$ & 3.70 & 74 & High \\
\hline 28 & $\begin{array}{l}\text { Speech exercises invite students to talk about their } \\
\text { concerns and interests }\end{array}$ & 3.30 & 66 & Moderate \\
\hline 29 & The time allotted for teaching the material is sufficient & 2.63 & 52.6 & Low \\
\hline \multicolumn{2}{|r|}{ Total score of Listening and Speaking sub-domain } & 3.35 & 67 & Moderate \\
\hline \multicolumn{2}{|c|}{ Total score of Textbook Content domain } & 3.16 & 63.2 & Moderate \\
\hline
\end{tabular}

The results of table (5) show the following:

\section{Reading and Writing:}

The degree of evaluation for reading and writing sub- domain was high on items $(13,15$, and 16)) where the percentages of response on these items were between (74\%-76.6\%). The degree was moderate on item (14) where the percentage of response on this item was $(65.6 \%)$. The degree was low on item (17) where the percentages of response on this item was $(59.2 \%) . \%)$. The degree was very low on item (18) where the percentage of response on this item was $(47 \%)$.

For the total score of the reading and writing sub- domain, the degree was high where the percentage of response was (70\%).

\section{Structure and Vocabulary:}

The degree of evaluation here for structure and vocabulary sub-domain was high on items $(19,20,21$, and 22) where the percentages of response on these items were between (70.2\%-76\%). The degree was moderate on item (23) where the percentage of response on this item was (66.2\%). The 
degree was very low on item (24) where the percentage of response on this item was $(44.2 \%)$.

For the total score of the structure and vocabulary sub- domain, the degree was high where the percentage of response was $(70.4 \%)$.

\section{Listening and Speaking:}

The degree of evaluation for listening and speaking sub- domain was high on items (25 and 27) where the percentages of response on these two items were respectively ( $73.4 \%$ and $74 \%$ ). The degree was moderate on items (26 and 28) where the percentage of response on these two items were respectively $(60 \%$ and $66 \%)$. The degree was low on item (29) where the percentage of response on this item was $(52.6 \%)$.

For the total score of the listening and speaking sub- domain, the degree was moderate where the percentage of response was $(67 \%)$.

D. Textbook- Teaching Aids Domain:

Table (6) Means and percentages of the Evaluation

\begin{tabular}{|c|c|c|c|c|}
\hline No & Items & *Means & Percent (\%) & Degree \\
\hline 30 & $\begin{array}{l}\text { The pictures and diagrams used are related to the } \\
\text { learners' background }\end{array}$ & 3.28 & 65.6 & Moderate \\
\hline 31 & $\begin{array}{l}\text { The aids and activities used help to build students' } \\
\text { confidence }\end{array}$ & 3.41 & 68.2 & Moderate \\
\hline 32 & The aids help to relieve anxiety and boredom & 3.21 & 64.2 & Moderate \\
\hline 33 & $\begin{array}{l}\text { The activities foster the spirit of independent } \\
\text { learning }\end{array}$ & 2.95 & 59 & Low \\
\hline 34 & They help to develop communicative skills & 3.58 & 71.6 & High \\
\hline 35 & They help to de- emphasize teacher's talk & 3.36 & 67.2 & Moderate \\
\hline \multicolumn{2}{|c|}{ Total score of Teaching Aids domain } & 3.29 & 65.8 & Moderate \\
\hline
\end{tabular}

The results of table (6) show that the degree of evaluation of teaching aids domain was high on item (34) where the percentages of response on this item was $(71.6 \%)$. The degree was moderate on items $(30,31,32$, and 35$)$ where the percentage of response on these items were between (64.2\%$68.2 \%$ ). The degree was low on item (33) where the percentage of response on this item was $(59 \%)$.

For the total score of the teaching aids domain, the degree was moderate where the percentage of response was $(65.8 \%)$.

II. Teacher's Manual

Table (7) Means and percentages of the Evaluation

\begin{tabular}{|c|l|c|c|c|}
\hline No & \multicolumn{1}{|c|}{ Items } & *Means & Percent (\%) & Degree \\
\hline \multicolumn{2}{|c|}{ A. General Features } & & & \\
\hline 36 & $\begin{array}{l}\text { Does the manual help teachers understand the } \\
\text { objectives and methodology of the text }\end{array}$ & 3.26 & 64.6 & Moderate \\
\hline 37 & $\begin{array}{l}\text { The correct or suggested answers are given for the } \\
\text { exercises in the textbook }\end{array}$ & 3.45 & 68.2 & Moderate \\
\hline
\end{tabular}




\begin{tabular}{|c|c|c|c|c|}
\hline \multicolumn{2}{|c|}{ Total score of General Features domain } & 3.22 & 65.2 & Moderate \\
\hline \multicolumn{5}{|c|}{ B. Background Information } \\
\hline 38 & $\begin{array}{l}\text { Teachers shown how to teach students to use cues } \\
\text { from morphology, cognates, rhetorical } \\
\text { relationships, and context to assist them in lexical } \\
\text { inference }\end{array}$ & 3.21 & 65.6 & Moderate \\
\hline 39 & $\begin{array}{l}\text { There is a list of true and false cognates for } \\
\text { vocabulary words }\end{array}$ & 3.60 & 73.6 & High \\
\hline \multicolumn{2}{|r|}{ Total score of Background Information domain } & 3.39 & 69.6 & Moderate \\
\hline \multicolumn{5}{|c|}{ C. Methodological Guidance } \\
\hline 40 & $\begin{array}{l}\text { Teachers are given techniques for activating } \\
\text { students' background knowledge before reading the } \\
\text { text }\end{array}$ & 4.01 & 81.2 & Very High \\
\hline 41 & $\begin{array}{l}\text { Teachers are given adequate examples for teaching } \\
\text { students to preview, skim, scan, summarize, and to } \\
\text { find the main idea }\end{array}$ & 2.85 & 58 & Low \\
\hline 42 & $\begin{array}{l}\text { The manual suggests a clear, concise method for } \\
\text { teaching each lesson }\end{array}$ & 3.36 & 67.2 & Moderate \\
\hline \multicolumn{2}{|r|}{ Total score of Methodological Guidance domain } & 3.40 & 68.8 & Moderate \\
\hline
\end{tabular}

The results of table (7) show the following:

\section{A- General Features}

The degree of evaluation of Teacher's Manual - General Features' domain was moderate on items ( 36 and 37) where the percentages of response on these two items were respectively (64.6\%-68.2\%).

For the total score of the general features domain, the degree was moderate where the percentage of response was (65.2\%).

\section{B- Background Information}

The degree of evaluation of Teacher's Manual - Background Information domain was high on item (39) where the percentage of response on this item was $(73.6 \%)$. The degree was moderate on item (38) where the percentage of response on this item was $(65.6 \%)$.

For the total score of the background information domain, the degree was moderate where the percentage of response was (69.6\%).

\section{C- Methodological Guidance}

The degree of evaluation of Methodological Guidance domain was very high on item (40) where the percentage of response on this item was (81.2\%). The degree was moderate on item (42) where the percentage of response on this item was (67.2\%). The degree was low on item (41) where the percentage of response on this item was $(58 \%)$. 
For the total score of the background information domain, the degree was moderate where the percentage of response was $(68.8 \%)$.

III. Rank Order of domains and total score of evaluation:

\section{1- Textbook}

Table (8): Means percentages and Ranks of English Skills and total ( $\mathrm{N}=76)$

\begin{tabular}{|c|c|c|c|c|}
\hline Domains & *Means & Percent $(\boldsymbol{\%})$ & Degree & Rank \\
\hline General Shape & 3.59 & 71.8 & High & 2 \\
\hline Objectives & 3.62 & 72.4 & High & 1 \\
\hline Content & 3.16 & 63.2 & Moderate & 4 \\
\hline Teaching Aids & 3.29 & 65.8 & Moderate & 3 \\
\hline Total Score & $\mathbf{3 . 3 5}$ & $\mathbf{6 7}$ & Moderate & \\
\hline
\end{tabular}

2- Teacher's Manual

Table (9): Means percentages and Ranks of English Skills and total (N=76)

\begin{tabular}{|c|c|c|c|c|}
\hline Domains & *Means & Percent $(\boldsymbol{\%})$ & Degree & Rank \\
\hline General Features & 3.22 & 65.2 & Moderate & 3 \\
\hline Background Information & 3.39 & 69.6 & Moderate & 1 \\
\hline Methodological Guidance & 3.40 & 68.8 & Moderate & 2 \\
\hline Total Score & $\mathbf{3 . 3 3}$ & $\mathbf{6 7 . 8}$ & Moderate & \\
\hline
\end{tabular}

\section{* Maximum point of response (3) points.}

The results of tables (8) and (9) show a moderate degree of evaluation of English Textbook "IRAQ OPPORTUNITIES" for the $2^{\text {nd }}$ Intermediate stage on total score, where the average of response in the Textbook and the Teachers' Guide were respectively (67\% and 67.8\%).

Furthermore, the results indicated that the ranks' order of evaluation of Textbook's domains are as follow:

First rank: Book Objectives Domain (72.4\%)

Second rank: Book General Shape Domain (71.8\%)

Third rank: Teaching Aids Domain (65.8\%)

Fourth rank: Book Content Domain (63.2\%)

While the results indicated that the ranks order of evaluation Teachers' Guide domains are as follow:

First rank: Background Information Domain (69.6\%)

Second rank: Methodological Guidance Domain (68.8\%)

Third rank: General Features Domain (65.2\%)

\section{- Results Related to the Second Aim}

The instrument of the present research consisted of one open question at the end of the questionnaire. The question was: What are your suggestions 


\section{and recommendations for developing English Textbook IRAQ}

OPPORTUINITIES for the $2^{\text {nd }}$ Intermediate Stage?In order to achieve the second aim of the present study, the researcher calculated frequencies and percentages of these suggestions and recommendations.

Table (10): frequencies and percentages of English teachers' suggestions and recommendations

\begin{tabular}{|c|c|c|c|}
\hline Domain & Suggestions and Recommendations & Frequencies & $\begin{array}{l}\text { Percentag } \\
\text { e }(\%)\end{array}$ \\
\hline $\begin{array}{c}\text { Textbook } \\
\text { general shape }\end{array}$ & The textbook should be free of mistakes & 21 & 35.7 \\
\hline $\begin{array}{l}\text { Textbook } \\
\text { objectives }\end{array}$ & $\begin{array}{l}\text { They should meet the individual differences among } \\
\text { students }\end{array}$ & 18 & 30.6 \\
\hline $\begin{array}{l}\text { Textbook } \\
\text { contents: } \\
\text { 1-Reading } \\
\text { and Writing }\end{array}$ & Should enhances free writing opportunities & 31 & 50.9 \\
\hline $\begin{array}{l}\text { 2-Structure } \\
\text { and } \\
\text { Vocabulary }\end{array}$ & $\begin{array}{l}\text { Grammar and vocabulary should be more appropriate } \\
\text { to the students' level }\end{array}$ & 22 & 35.8 \\
\hline $\begin{array}{l}\text { 3-Listening } \\
\text { and Speaking }\end{array}$ & $\begin{array}{l}\text { Speech exercises should be more attractive to invite } \\
\text { students to talk about their concerns and interests }\end{array}$ & 18 & 30.6 \\
\hline $\begin{array}{l}\text { Teaching } \\
\text { Aids }\end{array}$ & $\begin{array}{l}\text { The activities should foster the spirit of independent } \\
\text { learning }\end{array}$ & 12 & 25.4 \\
\hline $\begin{array}{l}\text { Teacher's } \\
\text { Manual: } \\
\text { 1-General } \\
\text { Features }\end{array}$ & $\begin{array}{l}\text { the manual should clarify objectives and } \\
\text { methodology of the text and help teachers to } \\
\text { understand them accurately }\end{array}$ & 17 & 29.1 \\
\hline $\begin{array}{c}\text { 2- } \\
\text { Background } \\
\text { Information }\end{array}$ & $\begin{array}{l}\text { Teachers should be well instructed on how to teach } \\
\text { students to use cues from morphology, cognates, } \\
\text { rhetorical relationships, and context to assist them in } \\
\text { lexical inference }\end{array}$ & 12 & 25.4 \\
\hline $\begin{array}{l}\text { 3- } \\
\text { Methodologic } \\
\text { al Guidance }\end{array}$ & $\begin{array}{l}\text { Teachers should be given adequate examples for } \\
\text { teaching students to preview, skim, scan, summarize, } \\
\text { and to find the main idea }\end{array}$ & 14 & 26.3 \\
\hline
\end{tabular}




\section{Discussion of the Results}

The results indicated that the rank order of evaluation domains was as follows:

1- Textbook: objective domain, general shape domain, teaching aids domain, book content domain respectively.

2- Teacher's Manual: Background Information, methodological guidance, and general features.

The teachers' evaluation of the textbook general shape was high. The researcher attributes such high degree to the great interest from the Ministry of Education and curriculum planners in the book shape, and in response to the general criteria of evaluating a textbook that many educationalists recommended, such as Romero,(1975), Daoud and CeleceMurcia,(1979), Al-Jarrah,(1987). The results are also in harmony with Masri, (2003).

However, the degree of evaluation was low on item 4 (the book is free of mistakes). This is consistent with Mahmoud, (2006) and El- Mustafa, (1988). On the other hand, Al-Jarrah's study revealed that the material was correct and accurate.

The book objectives were suitable. This is in line with Mu'men, (1992), Saleh, (1990). However, Lababidi, (1983) stated that the objectives of the textbook were not realized.

The degree of the objectives evaluation was low on item 11 (addressing the individual differences among students). This goes on with Masri,(2003), Badawi, (2002), Mu'men (1992).

This can be attributed to the fact that the teachers and students didn't participate in selecting the textbook objectives.

The reading texts were meaningful and authentic. However, some writings were difficult for most of the students. This is because students are required to write long paragraphs, essays or letters; they have also to deal with tables, figures and make comparisons.

On the other hand, all sorts of writings in the textbook are guided and controlled; this doesn't give a good chance for students to write freely and express themselves through writing what they feel, enjoy and prefer.

Structure, vocabulary, listening sand speaking were appropriate and helpful for the teachers; the exercises were relatively designed properly to suit the students' levels and interests.

The teaching aids were quite suitable since they can help to build selfconfidence, encourage students' thinking and encourage their communication. However, they need to be developed so as to achieve students' independent learning. 
The results showed that the time allotted for teaching the $2^{\text {nd }}$ intermediate stage English textbook was inadequate. The teachers agreed that all skills and activities being taught in this book need more time to deal with them more effectively. This agrees with Mahmoud,(2008), Martani,(1996) and Al- Jarrah,(1987).

The researcher attributes this to many factors:

1- The material is long. For example, each unit contains many new vocabulary words and two or more listening texts. This also applies to all other skills.

2- $\quad$ Students are still to some extent teacher-dependent.

3- Teachers are not well- trained enough to time their lessons properly and efficiently.

According to the teachers' manual results, they show moderate degree in the general features, background information and methodological guidance. But a low degree was shown in the methodological guidance in item (41) which indicates that "Teachers are not given adequate examples for teaching students to preview, skim, scan, summarize, and to find the main idea"

\section{Conclusion}

In reference to the results which have already been discussed in the present study, the researcher concluded that : there is a big lack in English textbook (IRAQ OPPORTUNITIES) for the $2^{\text {nd }}$ intermediate stage in most of its domains such as: Textbook: objective domain, general shape domain, teaching aids domain, book content domain respectively.

Teacher's Manual: Background Information, methodological guidance, and general features. The textbook's objectives do not meet the individual differences among students and the contents do not enhances free writing opportunities .

\section{Suggestions}

In the light of the review of the literature regarding good quality textbook, the researcher suggests the following criteria to be taken into account when selecting and evaluating an English textbook:

- General aims and specific objectives.

- $\quad$ The layout of the textbook.

- $\quad$ The content (material).

- $\quad$ Language skills. 
- $\quad$ Teaching aids.

- $\quad$ Methods of teaching.

- $\quad$ Time allotted for teaching.

- $\quad$ Students' needs and interests.

- $\quad$ Teacher's manual.

\section{Recommendations}

In the light of the findings of the study, the researcher presents the following recommendations:

\section{Firstly: for the Ministry of Education:}

1- The number of units of the $2^{\text {nd }}$ intermediate English Textbook should be minimized to enable the teachers to cover the material effectively on time.

2- $\quad$ Textbooks should be revised from time to time to make sure they are free from spelling and lexical mistakes.

3- Teachers should be consulted when selecting the textbook material, and they should participate in making any modifications or improvements concerning the textbooks.

4- It is recommended that the textbook be provided with a variety of literary forms in order to meet the needs, interests of the students and foster their reading for the sake of pleasure. For example, some poems and essays can be provided.

\section{Secondly: Recommendations for Teachers:}

1- $\quad$ Teachers should develop the teaching aids so as to be able to deal with the individual differences among students.

2- While teaching, teachers should always think about the timing of the lessons so that they can carry out the desired tasks, aims and activities effectively, and make a balance among the skills being taught.

3- Teachers are advised to train their students to think for themselves and be independent learners. This will help them deal with the problem of inadequate time allotted for teaching the textbook.

4- $\quad$ They have to be trained to employ modern technology such as computers and internet in order to meet the changing needs of the students, and make English teaching and learning more meaningful and enjoyable.

5- $\quad$ Teachers ought to provide students with additional writing texts so that they can express themselves through writing freely about their desires, needs, feelings,...etc.

\section{Thirdly: Recommendations for Further Studies}


1- Conducting evaluative studies on other English textbooks, especially the $1^{\text {st }}$ and $3^{\text {rd }}$ intermediate stages.

2- Conducting evaluative studies on the "Iraq Opportunities" curriculum in other districts. 


\section{REFERENCES:}

Al-Jarrah, Kh.(1987): "Analysis and Evaluation of New Textbook (PETRA) for the fifth and sixth elementary classes in Jordan".Unpublished MA Thesis. Yarmouk University, Jordan.

- Ansary. H. and Babai, E. (2002) "Universal Characteristics of Evaluation". The Internet TESL Journal 8/2. (March 9, 2003) Available: http://iteslj.org/Articles/Ansary-Textbook/

Azevendo, Milton. M. (1979): Trends in Elementary Spanish Texts. The Modern Language Journal.V13: No. 1\&2PP. 400-406

- $\quad$ Banks, James. A. \& Ambrose. A. Clegg, Jr. 1977. Teaching Strategies for the Social Studies: Inquiry, Valuating, and Decision Making. Massachusetts: Adison: Wesley Publishing Company.

- Chaplen. E.F. 1980 . "Collecting and Analysing student Evaluation of a Foreign Language Course". English Language Teaching Journal,Vol. XXXIV, No. 3.

- Daoud, A.M., \& Celce-Murcia, M. (1979). Selecting and evaluating a textbook. In M. Celce-Murcia and L. McIntosh (Eds.), Teaching English as a second or Foreign Language (pp. 302-307). New York, NY: Newbury House.

- $\quad$ El- Mustafa, A.M. (1988): An Evaluation of TEFL Textbook (PETRA) for the first preparatory class in Jordan. Unpublished Master's Thesis. Yarmouk University. Jordan.

- Forman, David. 1981. "Evaluation Training: Present and Future." Educational Technology. Vol. XX, No. 10.

Graves. K. (2000). Designing Language Course. Heinle \& Heinle publishers.

Lababidi,W.(1983). Towards a Communicative English Syllabus for the Compulsory Cycle in Jordan. Unpublished Master's Thesis. Yarmouk University, Irbid, Jordan

- $\quad$ Lamie. J (1999) "Making the textbook More Communicative". [online] The Internet

- Lee, J. 1975. "Choosing and Using a Textbook" English Language Teaching Forum. Vol. XIII, No. 3.

- Litz. D. (2001). Textbook Evaluation and ELT management: A South Korean Case Study.[online] UAE University of Al Amin. Available: http:// www.asian-efl-journal.com/Litz thesis. pdf

- $\quad$ Masri, Sa'eda.(2003). Teachers' Evaluation of First Graders' English for Palestine. in the Northern Directorates of Palestine. An-Najah National University, Nablus, Palestine. M.A Thesis

- Mariani, Charles. F. (1980). "Course Maintenance: The problems and Solutions". Educational Technology. Vol. XX, No. 12 .

Marteini,(1996): "Directions for Reform: Perceptions of Indonisian Students Towards English Language Curricula" Pro Quest, DAIA 57/ 10, pp. 218 
Matos. F,(2000): Teachers as a textbook evaluators: an interdisciplinary checklist. [ on line], IATEFL Associate Braz TESOL. Available: http:// www. Eayrs. Com/ELT/ publications/ JATEFL_ Issues/Archives/ Texts/ 157 Gomes_Martos/ htm/. - Mahmoud, A (2006) Analysing "English for Palestine 5th Textbook" in terms of the characteristics of a good English Textbook". The Islamic University Journal. Vol 15/1/2006

- Mu'men, G. (19920. Teachers' Evaluation of PETRA. The English Language Textbooks for the Seventh and Eighth Grades in Jordan. M.A. Thesis. University of Jordan, Amman, Jordan.

- Nevo, David, 1977. "A model for Utilization of Formative Evaluation in the Process of Developing Instructional Materials." PLETA, Journal. Vol. 14, No. 2 .

- $\quad$ Richard. J. C. (2001). Curriculum Development In Language Teaching. New York: Cambridge University Press.

Romero, R. (1975), What textbook shall we use? English Language Teaching Forum. Vol. 8, No. 304, pp. 30-33.

- $\quad$ Saleh, N. (1990). An Evaluation of the TEFL Textbook (PETRA) for the Second Preparatory Class in Jordan. Unpublished M.A. Thesis. Yarmouk University, Irbid, Jordan.

- $\quad$ Sawin, E.L. (1990). Evaluation and the Work of Teachers Wordsworth.

- Sheldon. L.E (1988). "Evaluating ELT Textbooks and Materials". [online].

English Language Teaching Journal 42/4. 237-246. Retrieved

- Taylor, L. (1990). Teaching and Learning Vocabulary. London: Prentice Hall.

- Williams, David. 1983. "Developing Criteria for Textbook Evaluation." ELT Journal. Vol. 36, No. 3. pp. 245-258.

- $\quad$ Wolf, R. M. (1979), Evaluation in Education, New York: Prager publishers.

Worthen, B. R. \& Sanders, J. R. (1987). Educational Evaluation. New York: Longman Inc. 


\section{تقويم كتاب اللغة الانكليزية (فرص العرق) كتاب (؟) للصف الثاني المتوسط} د. حنان ضياء عاكف

\section{جامعة بغداد/ كلية التربية للبنات - قسم اللغة الانكليزية}

الملخص:

إنَّ الباحث هو أستاذ مختص بتدريس اللغة الانكليزية ويهدف الى أجراء تقويم الى كتاب اللغة الانكليزية الذي

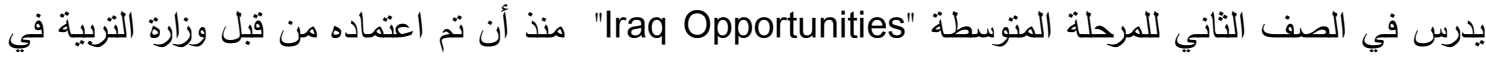

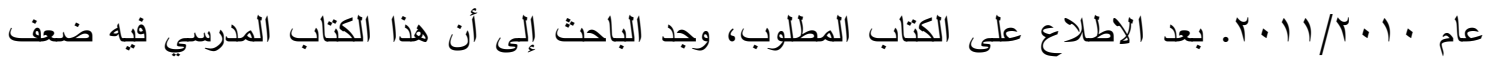

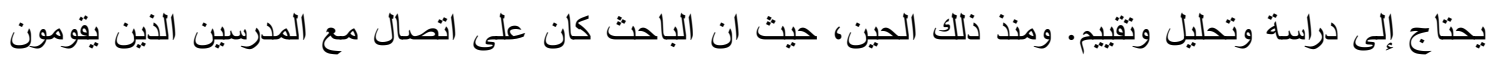
بتدريس هذا الكتاب الددرسي. حيث ان الكثير من المدرسين كان يشكو بعض الصعوبات في التعامل مع الكتاب

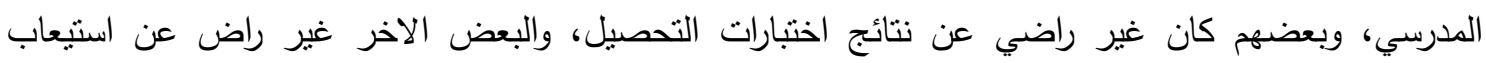
الطلاب لهذه المادة حيث انها تعاني من فقر في بعض عضن مكوناته. تهدف هذه الدراسة إلى: ا - ثقييم كتاب اللغة الانجليزية "Iraq Opportunities" للمرحلة المتوسطة الصف الثاني من وجهة نظر المدرسين.

$$
\text { ب - عرض مقترحات وتوصيات المدرسين التي ستساعد في تطوير المنهج. }
$$

I - كتاب اللغة الإنجليزية "Iraq Opportunities " للمرحلة المتوسطة الصف الثاني.

ץ - مدرسي اللغة الانكليزية المعنيين بتدريس مراحل الصف الثاني المتوسط الموجودة في بغداد الكرخ (1). وعرضت العديد من الدراسات السابقة ذات الصلة وتمت مناقشتها. 